\title{
KOMPOSISI JENIS, DISTRIBUSI, DAN KEPADATAN STOK IKAN EKOR TIKUS (MACROURIDAE) DI PERAIRAN LAUT DALAM ZONA EKONOMI EKSKLUSIF INDONESIA SAMUDERA HINDIA
}

\author{
Suprapto'1) \\ 1) Peneliti pada Balai Riset Perikanan Laut, Muara Baru-Jakarta \\ Teregristrasi I tanggal: 6 Oktober 2008; Diterima setelah perbaikan tanggal: 3 Nopember 2008; \\ Disetujui terbit tanggal: 13 Nopember 2008
}

\begin{abstract}
ABSTRAK
Penelitian ini bertujuan untuk mengkaji, komposisi jenis, penyebaran, dan kepadatan stok ikan ekor tikus (Macrouridae) di perairan laut dalam zona ekonomi eksklusif Indonesia Samudera Hindia meliputi selatan Jawa dan barat Sumatera. Data yang dianalisis merupakan sebagian hasil survei yang dilakukan bulan Juni sampai dengan Agustus 2005 dengan menggunakan K. R. Baruna Jaya (1.219 GT). Estimasi kepadatan stok dilakukan dengan menggunakan metode sapuan dengan pengambilan contoh acak bertingkat. Hasil penelitian menunjukkan bahwa, ikan ekor tikus (Macrouridae) yang tertangkap terdiri atas 35 spesies, mewakili 11 genera. Komposisi hasil tangkapan didominansi oleh spesies Caelorinchus divergens dan Caelorinchus smithi, (19,2 sampai dengan $77,2 \%$ ). Penyebaran laju tangkap secara horisontal, paling tinggi ditemukan di perairan selatan Jawa, sebaliknya semakin ke arah perairan barat Sumatera, cenderung rendah. Sedangkan secara vertikal, laju tangkap cenderung meningkat seiring dengan bertambah kedalaman. Laju tangkap paling tinggi pada umumnya berada pada kedalaman mulai dari 500 sampai dengan $1.200 \mathrm{~m}$. Jumlah spesies yang tertangkap pada kedalaman lebih dangkal (200 sampai dengan $300 \mathrm{~m}$ ) relatif sedikit, selanjutnya semakin bertambah kedalaman, jumlah spesies tersebut cenderung meningkat. Spesies yang memperlihatkan penyebaran paling luas terdiri atas Coryphaenoides sp. 1 dan Macrouridae sp.1. Kelimpahan stok ikan ekor tikus (Macrouridae) tertinggi ditemukan pada kisaran kedalaman 800 sampai dengan $900 \mathrm{~m}$ dan terendah pada kedalaman 200 sampai dengan $300 \mathrm{~m}$. Kepadatan stok di perairan sebelah selatan Jawa, berkisar antara 4 sampai dengan $1.221 \mathrm{~kg} \mathrm{~km}^{-2}$, rata-rata sekitar $336,53 \mathrm{~kg} \mathrm{~km}^{-2}$. Sedangkan di perairan barat Sumatera berkisar antara 0,85 sampai dengan $478,4 \mathrm{~kg} \mathrm{~km}^{-2}$, rata-rata sekitar $167,30 \mathrm{~kg} \mathrm{~km}^{-2}$.
\end{abstract}

KATAKUNCl: Macrouridae, komposisi jenis, distribusi, kepadatan stok, laut dalam, zona ekonomi eksklusif Indonesia Samudera Hindia

ABSTRACT: Spesies composition, distribution, and stock density of rattail fish (Macrouridae) in the deep sea of the Indonesian eks/usive economic zone of the Indian Ocean. By: Suprapto

The objective of this research is to study species composition, distribution, and stock density of rattail fish (Macrouridae) in the waters of southern Java and western Sumatera of the Indian Ocean Indonesian ekslusive economic zone. The study was done based on the data collected from the survey conducted between June and August 2005 using R. V. Baruna Jaya IV (1,219 GT). The study was basically conducted by applying swept area method with stratified random sampling. The results show that the species composition of rattail fish in the of the waters Indian Ocean consisted of 35 spesies and 11 genera. The catch of Macrouridae was dominated by Caelorinchus divergens and Caelorinchus smithi about 19.2 to $77.2 \%$. The widest species distribution of this resources was Coryphaenoides sp.1 and Macrouridae sp.1. The highest abundance of rattail fish resources was caught at the depth of 800 to $900 \mathrm{~m}$ and the lowest at the depth of 200 to $300 \mathrm{~m}$. Stock density in southern off Java waters ranging from 4 to $1.221 \mathrm{~kg} \mathrm{~km}^{-2}$ and about 0,85 to $478,4 \mathrm{~kg} \mathrm{~km}^{-2}$ in western off Sumatera waters.

\section{KEYWORDS: Macrouridae, spesies composition, distribution, stock density, deep sea, Indian} Ocean

\section{PENDAHULUAN}

Ikan ekor tikus (Macrouridae) termasuk salah satu komunitas ikan demersal laut dalam, tergolong dalam kelas Osteichthyes, ordo Gadiformes, sub ordo Macrouroidea dan famili Macrouridae (Nelson, 1984).
Famili Macrouridae dikenal sebagai keluarga ikan grenadir atau ikan ekor tikus (rattails), karena hampir semua anggota kerabat tidak memiliki sirip caudal. Sirip dorsal dan sirip anal yang masing-masing memanjang dan menyatu ke arah ekor, meruncing tajam menyerupai bentuk ekor tikus. Jumlah spesies 
yang pernah diketahui terdiri atas 250 , di mana pada umumnya paling beragam berada pada kedalaman $>500$ m (Webber \& Thurman, 1991). Gambar 1, memperlihatkan foto beberapa genera ikan ekor tikus (Macrouridae) yang tertangkap di perairan zona ekonomi eksklusif Indonesia Samudera Hindia.

Komunitas ikan ekor tikus (Macrouridae) diketahui sebagai penghuni laut dalam (>200 m), jarang ditemukan pada perairan yang dangkal. Daerah sebaran cukup luas, dapat ditemukan di wilayah tropis sampai dengan sub tropis pada kedalaman 250 sampai dengan 2.000 m (Migdalsky \& Fichter, 1983), bahkan mampu beradaptasi pada kedalaman melebihi 5.000 m (Iwamoto,1977 dalam Carpenter \& Niem, 1999). Ikan-ikan ini berperan sebagai predator dalam siklus rantai pakan di laut dalam, sehingga memiliki peranan sangat penting dalam arti ekologi perairan. Hidup selalu bergerombol membentuk scholing relatif berlimpah pada habitat dekat dasar atau kadangkadang berenang-renang di sekitar kolom air (wilayah bento pelagis) untuk mencari makan atau melalukan aktivitas reproduksi (Midalsky \& Fichter, 1983; Frasser, 1975), sehingga mudah diburu dan ditangkap dengan alat tangkap jaring trawl dasar.

Ikan ekor tikus (Macrouridae) dapat dimanfaatkan sebagai konsumsi maupun dikembangkan pemanfaatan untuk keperluan medis dalam bidang kedokteran. Peluang tersebut dapat dimungkinkan, karena kandungan nutrisi tinggi dan memiliki komponen bioaktif dengan senyawa kimia yang khas. Di Kanada, ikan ekor tikus (Macrouridae) yang banyak tertangkap sebagai hasil sampingan pada perikanan turbot di perairan Greenland, sudah mulai dimanfaatkan sebagai alternatif komoditas perikanan laut dalam yang memberikan peluang untuk dikonsumsi. Berasa ringan (mild) dengan aroma yang harum gurih seperti ikan kod, tetapi lebih manis. Tekstur daging putih, tipis, dan berlapis-lapis (Perkin, 1992). Hasil analisis kandungan nutrisi untuk $100 \mathrm{~g}$ daging mentah terhadap ikan ekor tikus (Macrouridae) spesies Macrourus berglax diinformasikan mengandung protein $23,8 \mathrm{~g}$, lemak (fat) $0,3 \mathrm{~g}$, sodium $96,0 \mathrm{ml}$, dan kolesterol 54,0 $\mathrm{ml}$. Kandungan nutrisi tersebut cenderung lebh tinggi dibandingkan dengan ikan-ikan laut dalam lain, seperti ikan skate (Rajidae), monkfish (Lophius americanus), dan kingklip (Genypterus spp.). Di New Zealand, komposisi proximate ikan ekor tikus spesies Caelorinchus sp. mengandung $84 \mathrm{kcal}, 18,5 \mathrm{~g}$ protein, 0,5 g lemak, $0,9 \mathrm{~g}$ abu, dan $30,1 \mathrm{~g}$ omega-3. Sedangkan spesies Macrourus carinatus kandungan kalori $80 \mathrm{kcal}$, protein $17,4 \mathrm{~g}$, lemak 0,6 g, dan abu 0,9 g (Perkins, 1992). Hasil analisis kandungan nutrisi beberapa spesies ikan laut dalam yang diperoleh dari hasil tangkapan di perairan barat Sumatera (Samudera Hindia) memiliki kandungan protein berkisar 23,0 sampai dengan $24,8 \%$ (Suseno et al., 2007).

Menurut Barton (1977), kebanyakan organisme laut dalam, memiliki metabolit sekunder yang mengandung komponen bioaktif dengan senyawa kimia sangat spesifik, di mana tidak umum dijumpai pada komunitas ikan laut dangkal. Metabolit tersebut diprediksi terbentuk sebagai konsekuensi adaptasi secara fisiologi maupun biokimia bagi organisme yang hidup di laut dalam, di mana kondisi lingkungan sangat ekstrim (Nybakken, 1988). Senyawa hasil metabolit sekunder di organisme-organisme hidup merupakan unsur yang dipakai sebagai alat penangkal terhadap serangan penyakit, sekaligus sebagai sarana untuk mempertahankan hidup organisme. Oleh karena itu, ikan laut dalam memiliki potensi biokimiawi yang sangat penting untuk dikembangkan pemanfaatan bagi keperluan obat-obatan (medical) di masa akan datang (Barton, 1977). Berkaitan dengan hal tersebut. Suseno et al. (2007) menginformasikan hasil kajian bahwa, ekstrak daging beberapa spesies ikan laut dalam yang tertangkap dari perairan selatan Jawa, terbukti memiliki kandungan senyawa bioaktif yang mampu menghambat pertumbuhan bakteri Staphylococcus aureus dan bakteri Eschericia coli.

Informasi tentang pengkajian stok sumber daya ikan laut dalam di perairan zona ekonomi eksklusif Indonesia Samudera Hindia, secara umum telah dikatakan Suman et al. (2007); Badrudin et al. (2006); Badrudin et al. (2007a); Badrudin et al. (2007b);dan Wudianto \& Fayakun (2007). Tulisan ini akan mengkaji komoditas ikan ekor tikus (Macrouridae) sebagai bagian dari hasil tangkapan ikan demersal laut dalam di perairan zona ekonomi eksklusif Indonesia Samudera Hindia, dengan topik bahasan tentang komposisi jenis, daerah sebaran, dan dugaan potensi kepadatan stok. Diharapkan informasi ini dapat digunakan sebagai salah satu data dukung pengkajian stok dalam upaya pemanfaatan dan pengelolaan sumber daya ikan laut dalam di Indonesia. 


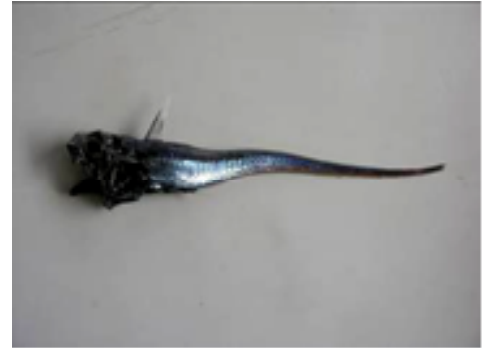

Hymenocephalus sp.

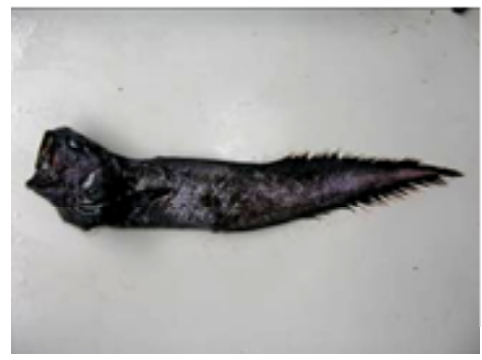

Ventrifossa sp.

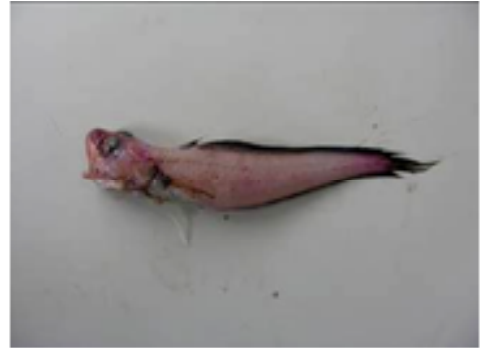

Bathygadus sp.

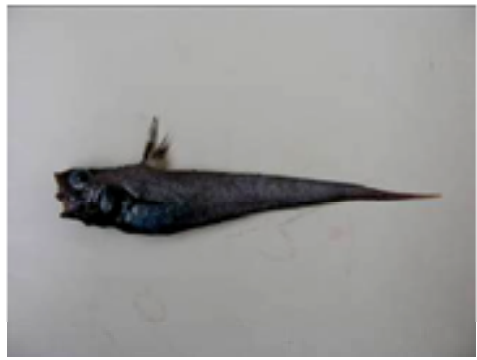

Monomitopus sp.

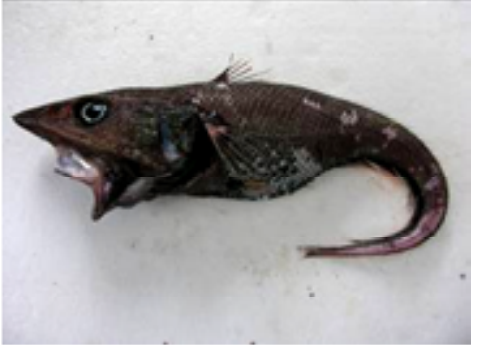

Caelorinchus sp.

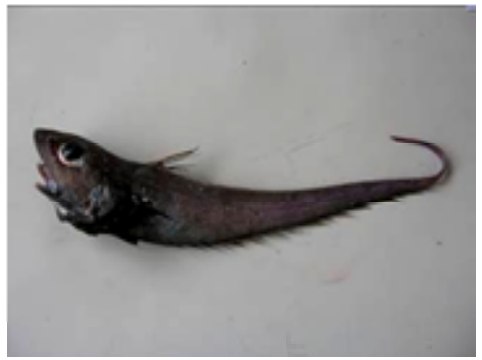

Nezumia sp.

Gambar 1. Foto beberapa genera ikan ekor tikus dari famili Macrouridae.

Figure 1. The photo of some genus Macrouridae.

\section{BAHAN DAN METODE}

Data dan informasi tentang jenis-jenis ikan ekor tikus (Macrouridae), dihimpun dari hasil riset kerja sama yang dilakukan antara pemerintah Indonesia (Badan Riset Kelautan dan Perikanan-Departemen Kelautan dan Perikanan) dan Jepang (Overseas Fishery Coorperation Foundation) pada bulan Juni sampai dengan Agustus 2005, di perairan laut dalam zona ekonomi eksklusif Indonesia (meliputi kawasan perairan selatan Jawa dan barat Sumatera). Sarana kapal yang digunakan adalah kapal riset Baruna Jaya IV (1.219 GT), sedangkan tipe alat tangkap yang digunakan adalah pukat dasar (otter bottom traw) memiliki panjang tali ris atas (head rope) sekitar 31,6 $\mathrm{m}$. Alat ini merupakan jaring trawl yang telah dimodifikasi khusus untuk pengoperasian di perairan laut dalam dan dilengkapi alat bantu echosounder, net sounder, dan fish finder.

Kegiatan penangkapan ikan dilakukan siang sampai dengan sore hari, pukul 08.00 sampai dengan 18.00 dengan metode sapuan area (swept area methode). Lokasi stasiun penangkapan dipilih secara acak berdasarkan pada kelayakan dasar perairan untuk pengoperasian jaring trawl. Lama waktu yang diperlukan dalam 1 kali penarikan jaring pada tiap stasiun (towing time) rata-rata 30 menit dengan kecepatan kapal, rata-rata 3 knot. Jenis-jenis ikan yang tertangkap diidentifikasi menggunakan buku Gloerfelt \& Kailola (1984); Carpenter \& Niem (1998);
Nakabo (2002). Untuk keperluan analisis, data yang digunakan adalah spesies ikan ekor tikus yang termasuk dalam famili Macrouridae, kemudian masingmasing jenis dihitung jumlah individu dan ditimbang bobot untuk mendapatkan data laju tangkap, yang selanjutnya digunakan sebagai dasar penghitungan kepadatan (biomass).

Informasi komposisi jenis, dianalisis secara deskriptip berdasarkan pada hasil perhitungan sederhana, yang disajikan dalam bentuk tabulasi nilai persentase bobot total ikan ekor tikus (Macrouridae) yang tertangkap. Penghitungan kepadatan ikan menggunakan metode sapuan menurut Sparre \& Venema (1992) dengan persamaan:

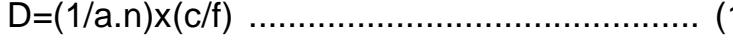

$$
\begin{aligned}
& \text { a. } n=t \times v x h \times e x 1,852 \times 0,001
\end{aligned}
$$

di mana:

$\mathrm{D}=$ kepadatan/density $\left(\mathrm{kg} \mathrm{km}^{-2}\right)$

a.n = luas daerah sapuan/swept area $\left(\mathrm{km}^{2}\right)$

$\mathrm{C}=$ hasil tangkapan/catch rate ( $\mathrm{kg}$ per jam)

$\mathrm{f}=$ escapment factor $(=0,5)$

$\mathrm{t}=$ lama penarikan jaring/towing time (0,5jam)

$\mathrm{v}=$ kecepatan $\mathrm{kapal} / \mathrm{speed}$ of ship (knot)

$\mathrm{h}=$ panjang tali ris atas/head rope $(31,6 \mathrm{~m})$

$\mathrm{e}=$ konstante bukaan mulut jaring/ constante of net mouth aperture $=0,66$ (Shindo, 1973) 


\section{HASIL DAN BAHASAN}

\section{Komposisi Jenis}

Hasil tangkapan ikan ekor tikus (Macrouridae) di perairan zona ekonomi eksklusif Indonesia Samudera Hindia, diperoleh 35 spesies, mewakili 11 genera. Genera Caelorinchus memperlihatkan keragaman spesies paling banyak (10 spesies) dibandingkan dengan genera-genera lain dalam 1 famili Macrouridae.
Di wilayah perairan lain, informasi keragaman spesies dari famili Macrouridae yang pernah tertangkap jaring trawl, jumlah sangat bervariasi. Gloerfelt \& Kailola (1984) mengatakan bahwa, di perairan sebelah selatan Indonesia sampai dengan barat laut Australia hanya 10 spesies. Sedangkan di perairan sebelah barat Laut Pasifik dapat mencapai 94 spesies, mewakili 16 genera (Iwamoto,1997 dalam Carpenter \& Niem, 1999).

Tabel 1. Komposisi jenis ikan Macrouridae yang tertangkap jaring traw/di perairan laut dalam selatan Jawa dan barat Sumatera

Table1. Catch composition of Macrouridae in deep sea southern Java and western Sumatera waters

\begin{tabular}{|c|c|c|c|c|c|}
\hline \multirow[t]{2}{*}{ No. } & \multirow[t]{2}{*}{ Jenis/Species } & \multicolumn{2}{|c|}{$\begin{array}{l}\text { Selatan Jawa/ } \\
\text { Southern Java }\end{array}$} & \multicolumn{2}{|c|}{$\begin{array}{l}\text { Barat Sumatera/ } \\
\text { Western Sumatera }\end{array}$} \\
\hline & & kg & $\%$ & kg & $\%$ \\
\hline 1. & Abyssicola macrochir & 1,10 & 0,21 & - & - \\
\hline 2. & Abyssicola sp. & 0,19 & 0,04 & - & - \\
\hline 3. & Bathygadus sp. & 2,48 & 0,48 & 0,35 & 0,14 \\
\hline 4. & Caelorinchus breviostris & 3,35 & 0,65 & - & - \\
\hline 5. & Caelorinchus cingulatus & 0,82 & 0,16 & 0,58 & 0,24 \\
\hline 6. & Caelorinchus divergens & 145,86 & 28,34 & 186,34 & 77,29 \\
\hline 7. & Caelorinchus japonicus & 6,97 & 1,35 & - & - \\
\hline 8. & Caelorinchus longissimus & 0,07 & 0,01 & - & - \\
\hline 9. & Caelorinchus kamoharai & 58,53 & 11,37 & - & - \\
\hline 10. & Caelorinchus smithi & 98,96 & 19,23 & 2,81 & 1,17 \\
\hline 11. & Caelorinchus sp.1 & 83,33 & 16,19 & 8,76 & 3,63 \\
\hline 12. & Caelorinchus sp.2 & 15,09 & 2,93 & 3,03 & 1,26 \\
\hline 13. & Caelorinchus sp.3 & 18,99 & 3,69 & - & - \\
\hline 14. & Coryphaenoides armatus & 2,60 & 0,51 & - & - \\
\hline 15. & Coryphaenoides marginatus & 10,25 & 1,99 & - & - \\
\hline 16. & Coryphaenoides sp.1 & 20,85 & 4,05 & - & - \\
\hline 17. & Coryphaenoides sp.2 & 2,71 & 0,53 & - & - \\
\hline 18. & Coryphaenoides sp.3 & 1,09 & 0,21 & - & - \\
\hline 19. & Gadamus colletti & 9,64 & 1,87 & 8,19 & 3,40 \\
\hline 20. & Hymenocephalus longiceps & 0,01 & 0,00 & - & - \\
\hline 21. & Hymenocephalus sp. & 0,09 & 0,02 & 0,03 & 0,01 \\
\hline 22. & Malacocephalus nipponensis & 0,93 & 0,18 & - & - \\
\hline 23. & Malacocephalus sp. & 1,05 & 0,20 & 5,00 & 2,07 \\
\hline 24. & Nezumia sp.1 & 9,19 & 1,79 & 3,09 & 1,28 \\
\hline 25. & Nezumia sp.2 & 0,56 & 0,11 & 2,47 & 1,02 \\
\hline 26. & Pseudonezumia japonica & 0,66 & 0,13 & 0,19 & 0,08 \\
\hline 27. & Ventrifossa fusca & 2,65 & 0,51 & - & - \\
\hline 28. & Ventrifossa sp.1 & 7,52 & 1,46 & 13,62 & 5,65 \\
\hline 29. & Ventrifossa sp.2 & 0,65 & 0,13 & 6,36 & 2,64 \\
\hline 30. & Ventrifossa sp.3 & - & - & 0,04 & 0,01 \\
\hline 31. & Ventrifossa sp.4 & - & - & 0,27 & 0,11 \\
\hline 32. & Macrouridae sp.1 & 2,16 & 0,42 & & \\
\hline 33. & Macrouridae sp. 2 & 1,11 & 0,22 & - & - \\
\hline 34. & Macrouridae sp.3 & 1,46 & 0,28 & - & - \\
\hline 35. & Macrouridae sp.4 & 3,77 & 0,73 & - & - \\
\hline & Jumlah/Total catch (kg) & 514,62 & & 241,08 & \\
\hline
\end{tabular}


Ikan ekor tikus (Macrouridae) yang mendominansi hasil tangkapan di kawasan perairan zona ekonomi eksklusif Indonesia Samudera Hindia terutama di bagian selatan Jawa adalah spesies Caelorinchus divergens dan Caelorinchus smithi, masing-masing mendominansi 28,3 dan $19,2 \%$. Kondisi hampir sama juga ditemukan di perairan barat Sumatera, di mana spesies Caelorinchus divergens mendominansi hasil tangkapan $77,2 \%$ (Tabel 1). Dominansi genera Caelorinchus juga pernah didapatkan pada hasil penelitian Anggrijani (1993) di perairan Tanimbar.

\section{Distribusi Horisontal}

Dari total 102 lokasi stasiun penangkapan, hampir semua stasiun mendapatkan spesies ikan Macrouridae dengan laju tangkap yang bervariasi, berkisar antara 0,03 sampai dengan $35,90 \mathrm{~kg}$. Laju tangkap terpadat, cenderung berada di perairan selatan Jawa, kemudian semakin ke arah perairan barat Sumatera relatif rendah (Gambar 2). Fenomena variasi pemusatan daerah sebaran tersebut, diduga dipengaruhi oleh faktor kontur dasar perairan maupun erat kaitan dengan faktor lingkungan yang cocok bagi kehidupan ikan. Seperti diketahui dari hasil pemantauan dasar perairan menggunakan echo sounder memperlihatkan bahwa sebagian besar topografi dasar perairan di kawasan barat Sumatera banyak bergunung-gunung dan bertebing curam dengan substrat dasar keras. Kondisi topografi yang demikian, menurut Egletton (1980), merupakan salah satu faktor pembatas penyebaran organisme laut dalam. Sebaliknya di selatan Jawa, dasar perairan sebagian besar relatif landai dan substrat dasar terdiri atas lumpur lunak, yang menggambarkan lingkungan yang cocok bagi kehidupan ikan demersal sehingga akan memperlihatkan pemusatan populasi yang tinggi (Widodo, 1980). Di perairan Tanimbar, Anggrijani (1993) mengatakan bahwa, pusat penyebaran ikan Macrouridae berada pada perairan sebelah tenggara Pulau Selaru, kemudian semakin ke arah timur, kepadatan meningkat mencapai 20 sampai dengan $180 \mathrm{~kg} \mathrm{~km}^{-2}$.

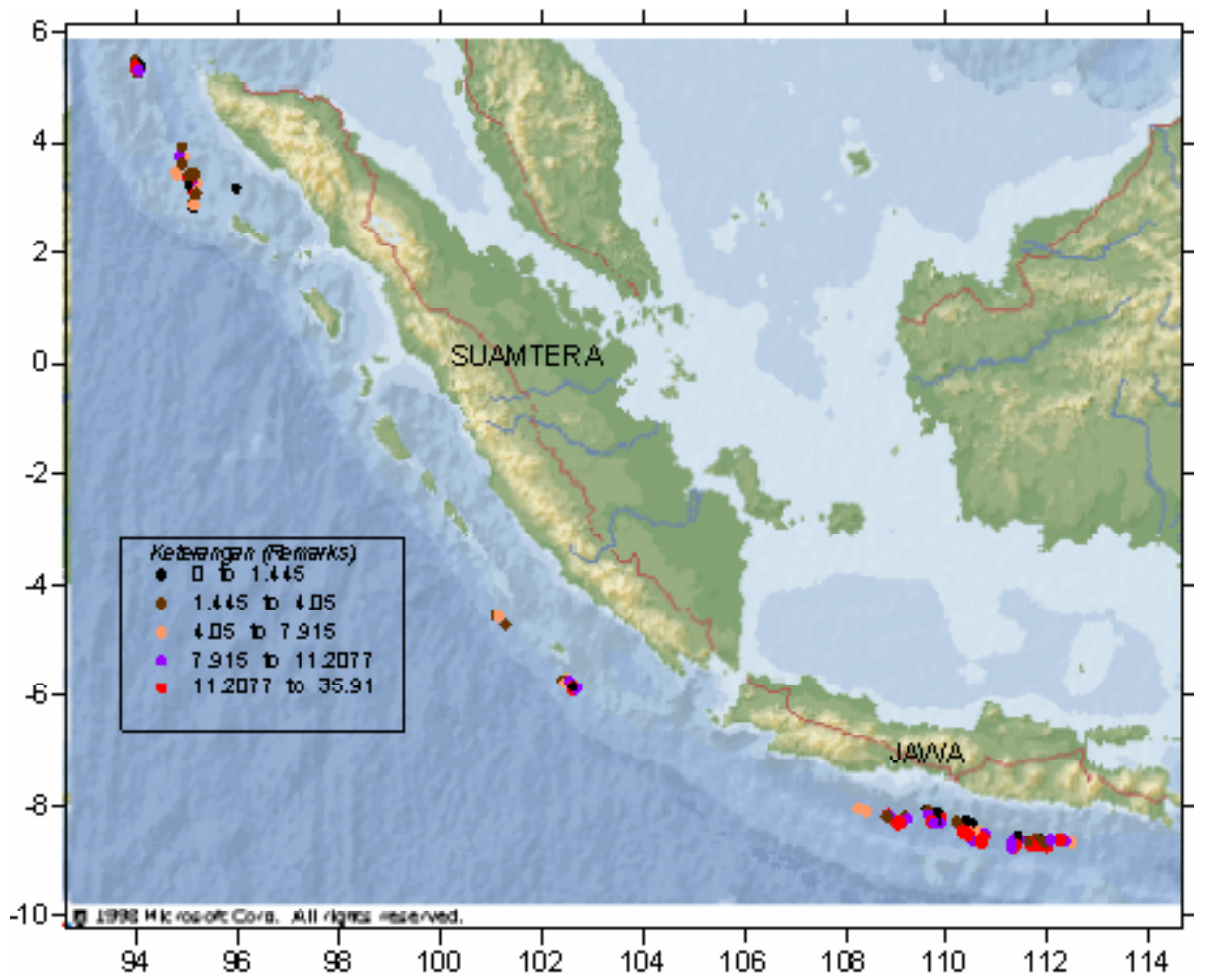

Gambar 2. Pola distribusi horisontal, laju tangkap ikan Macrouridae di perairan laut dalam zona ekonomi eksklusif Indonesia Samudera Hindia.

Figure 2. Pattern of catch rate horizontal distribution of Macrouridae in Indonesian ekslusive economic zone Indian Ocean deep sea.

\section{Distribusi Vertikal}

Sesuai dengan kapasitas tali wire yang tersedia di kapal, maka kegiatan penangkapan ikan laut dalam dilakukan pada kisaran 200 sampai dengan $1.200 \mathrm{~m}$.
Hampir seluruh kedalaman tersebut, tertangkap spesies ikan Macrouiridae, dengan variasi sebaran spesies dan pola sebaran laju tangkap seperti tampak pada Tabel 2 dan Gambar 3. 
Tabel2. Sebaran jenis ikan ekor tikus (Macrouridae) secara vertikal pada kisaran kedalaman 200 sampai dengan 1.200 m di perairan zona ekonomi eksklusif Indonesia Samudera Hindia.

Table 2. Vertical distribution of Macrouridae on range depth 200 to $1200 \mathrm{~m}$, in Indonesian ekslusive economic zone Indian Ocean waters

\begin{tabular}{|c|c|c|c|c|c|c|c|c|}
\hline \multirow{2}{*}{ Spesies/Species } & \multicolumn{8}{|c|}{ Kisaran kedalaman (m)/Range depth (m) } \\
\hline & $200-300$ & $>300-400$ & $>400-500$ & $>500-600$ & $>600-700$ & $>700-800$ & $>800-900$ & $>900-1200$ \\
\hline Abyssicola macrochir & - & - & - & - & 13 & - & 1 & 1 \\
\hline Abyssicola sp. & - & - & - & - & - & - & 1 & - \\
\hline Bathygadus sp. & - & - & - & 1 & - & 6 & 6 & 2 \\
\hline Caelorinchus breviostris & - & - & - & - & - & - & 21 & 3 \\
\hline Caelorinchus cingulatus & - & 11 & 30 & 11 & - & - & - & - \\
\hline Caelorinchus divergens & - & 18 & 3 & 47 & 188 & 347 & 550 & 60 \\
\hline Caelorinchus japonicus & - & - & - & - & 8 & - & - & 22 \\
\hline Caelorinchus kamoharai & 10 & 856 & 190 & 29 & 15 & 21 & 26 & - \\
\hline Caelorinchus longissimus & 33 & - & - & - & - & - & - & - \\
\hline Caelorinchus smithi & - & 1 & - & 50 & 147 & 127 & 189 & 72 \\
\hline Caelorinchus sp.1 & - & 5 & - & 70 & 51 & 63 & 85 & 10 \\
\hline Caelorinchus sp. 2 & - & 2 & - & 21 & 19 & 23 & 74 & 3 \\
\hline Caelorinchus sp.3 & - & 45 & - & 45 & - & 7 & - & - \\
\hline Coryphaenoides armatus & - & - & - & - & - & 1 & 19 & 2 \\
\hline Coryphaenoides marginatus & - & - & - & - & 1 & 30 & 24 & 43 \\
\hline Coryphaenoides sp.1 & 30 & 1 & 1 & 2 & 19 & 16 & 58 & 19 \\
\hline Coryphaenoides sp.2 & - & - & - & - & 16 & 3 & 6 & - \\
\hline Coryphaenoides sp.3 & - & - & - & - & 1 & - & 5 & - \\
\hline Gadamus colletti & - & - & - & 3 & 16 & 34 & 104 & 32 \\
\hline Hymenocephalus longiceps & - & 1 & - & - & - & - & - & - \\
\hline Hymenocephalus sp. & - & 9 & 4 & - & - & - & - & - \\
\hline Macrouridae sp.1 & 7 & 4 & 4 & 10 & 2 & 2 & 2 & 5 \\
\hline Macrouridae sp.2 & - & 19 & 1 & 13 & - & - & - & 1 \\
\hline Macrouridae sp.3 & - & - & - & 26 & - & - & - & 1 \\
\hline Macrouridae sp.4 & - & - & - & - & - & - & - & 15 \\
\hline Malacocephalus nipponensis & - & - & - & - & 4 & - & - & - \\
\hline Malacocephalus sp. & - & - & 55 & 8 & 8 & - & 41 & - \\
\hline Nezumia sp.1 & - & 7 & - & 32 & 27 & 36 & 51 & 6 \\
\hline Nezumia sp.2 & - & - & - & - & 3 & 16 & 31 & - \\
\hline Pseudonezumia japonica & - & - & - & - & 18 & - & 15 & - \\
\hline Ventrifossa fusca & - & - & - & - & 18 & 18 & - & - \\
\hline Ventrifossa sp. 1 & - & 76 & 122 & 20 & 59 & 29 & 135 & 7 \\
\hline Ventrifossa sp. 2 & - & 64 & - & 8 & 2 & 3 & 1 & - \\
\hline Ventrifossa sp. 3 & - & - & - & 1 & - & - & - & - \\
\hline Ventrifossa sp.4 & - & - & - & 2 & - & - & - & - \\
\hline $\begin{array}{l}\text { Jumlah jenis/ } \\
\text { Total species }\end{array}$ & 4 & 15 & 9 & 19 & 21 & 18 & 22 & 18 \\
\hline $\begin{array}{l}\text { Jumlah individu/ } \\
\text { Total individu }\end{array}$ & 80 & 1119 & 410 & 399 & 635 & 782 & 1445 & 304 \\
\hline
\end{tabular}

Tabel 2 memperlihatkan bahwa, jumlah spesies yang tertangkap pada kedalaman lebih dangkal (200 sampai dengan $300 \mathrm{~m}$ ) relatif sedikit (4 spesies), kemudian semakin dalam perairan cenderung lebih banyak. Jumlah spesies terbanyak, ditemukan pada kisaran kedalaman 800 sampai dengan $900 \mathrm{~m}$, yakni terdiri atas 22 spesies. Spesies yang memperlihatkan penyebaran paling luas Coryphaenoides sp. 1 dan Macrouridae sp.1, menyebar pada seluruh strata kedalaman mulai dari kedalaman 200 sampai dengan 1.200 m. Berikut Caelorinchus kamoharai (pada kisaran kedalaman 200 sampai dengan $900 \mathrm{~m}$ ), Caelorinchus divergens dan Ventrifossa sp.1, masingmasing menyebar pada kisaran kedalaman 300 sampai dengan $1.200 \mathrm{~m}$. Sebaliknya, yang memperlihatkan penyebaran relatif terbatas terdiri atas Caelorinchus longissimus (pada kisaran kedalaman
200 sampai dengan $300 \mathrm{~m}$ ), Hymenocephalus longiceps (pada kisaran kedalaman 300 sampai dengan $400 \mathrm{~m}$ ), Abyssicola sp. (pada kisaran kedalaman 800 sampai dengan 900 m), Caelorinchus japonicus (pada kisaran kedalaman 600 sampai dengan $700 \mathrm{~m}$ ), Caelorinchus longissimus (pada kisaran kedalaman 200 sampai dengan $300 \mathrm{~m}$ ), Coryphaenoides sp. 3 (pada kisaran kedalaman 800 sampai dengan $900 \mathrm{~m}$ ), Malacocephalus nipponensis (pada kisaran kedalaman 600 sampai dengan $700 \mathrm{~m}$ ), Ventrifossa fusca (pada kisaran kedalaman 700 sampai dengan $800 \mathrm{~m}$ ), Ventrifossa sp.3 dan Ventrifossa sp. 4 masing-masing pada kisaran kedalaman 500 sampai dengan $600 \mathrm{~m}$.

Bila diperhatikan laju tangkap pada setiap kedalaman, ikan ekor tikus (Macrouridae) yang 
tertangkap memperlihatkan laju tangkap yang bervariasi, seperti tampak pada Gambar 3. Tampak bahwa laju tangkap cenderung meningkat seiring dengan bertambah kedalaman. Laju tangkap paling tinggi pada umumnya berada pada kedalaman mulai dari 500 sampai dengan $1.200 \mathrm{~m}$.

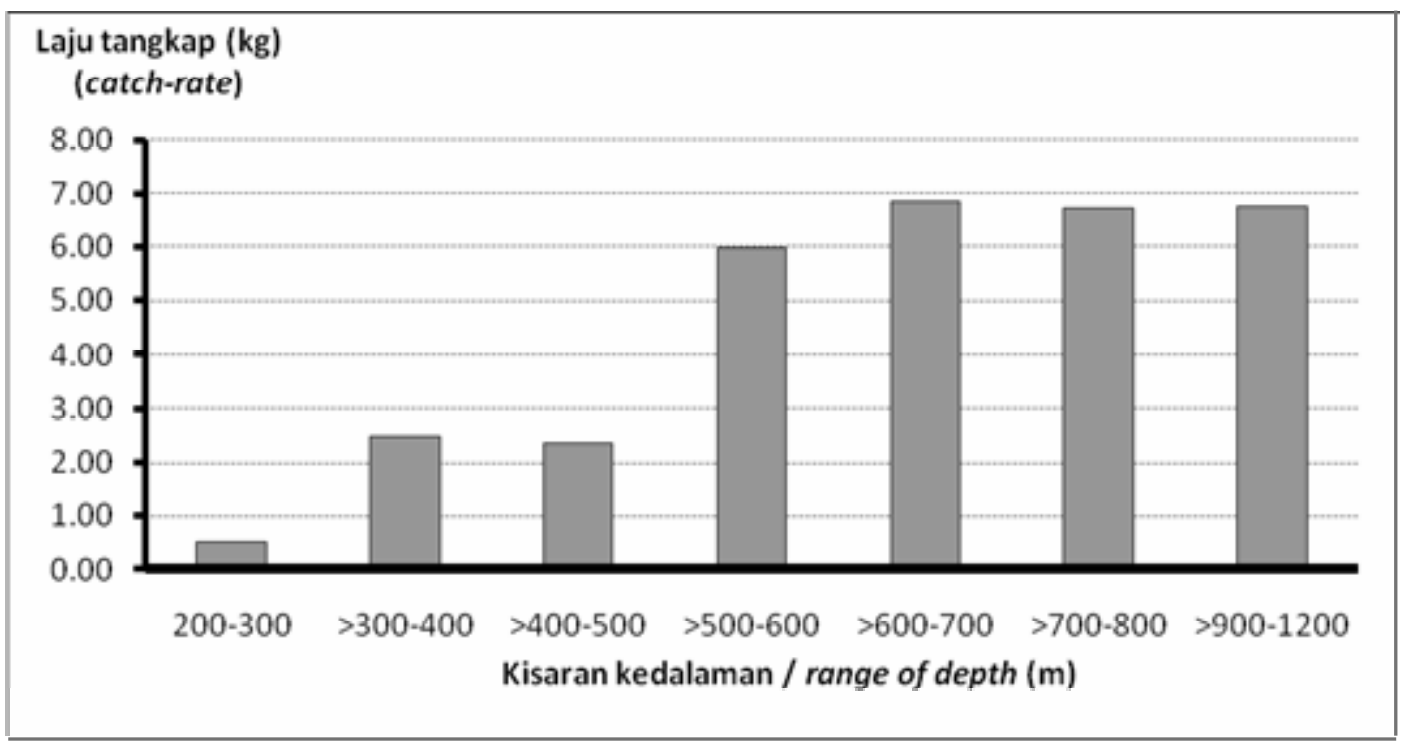

Gambar 3. Variasi laju tangkap ikan ekor tikus (Macrouridae) pada tiap selang kedalaman $100 \mathrm{~m}$, di perairan laut dalam zona ekonomi eksklusif Indonesia Samudera Hindia.

Figure 3. Catch rate variation of Macrouridae on range depth $100 \mathrm{~m}$, in Indonesian ekslusive economic zone Indian Ocean deep sea.

Di wilayah perairan kawasan timur Indonesia seperti sekitar Kepulauan Kai, kelompok famili Macrouridae diketahui berlimpah pada kedalaman 700-800 m, sedangkan di Kepulauan Tanimbar pada kedalaman 200 sampai dengan 300 dan 400 sampai dengan 500 m (Anggrijani, 1993). Sementara itu, di kawasan barat Indonsia, khususnya perairan sebelah selatan Cilacap, dikatakan berlimpah pada kedalaman 500 sampai dengan 100 m (Guntara, 2004).

\section{Kepadatan Stok}

Hasil perhitungan luas lahan yang tersapu pada setiap stasiun penangkapan, diperoleh nilai 0,0588 $\mathrm{km}^{2}$. Berdasarkan pada nilai tersebut, maka hasil perhitungan kepadatan stok pada masing-masing lahan stasiun penangkapan (catch per unit area) seperti pada Tabel 3.

Tabel 3 menunjukkan bahwa, kepadatan stok ikan ekor tikus (Macrouridae) di perairan laut dalam sebelah selatan Jawa, berkisar 4 sampai dengan $1.221 \mathrm{~kg} \mathrm{~km}^{-2}$, kepadatan stok rata-rata sekitar 336,53 $\mathrm{kg} \mathrm{km}^{-2}$. Stok terendah berada pada stasiun 1 (perairan sebelah selatan Cilacap), sebaliknya tertinggi pada stasiun 32 dan 39 (perairan sebelah selatan Pacitan dan selatan Tulung Agung). Secara spasial, tampak bahwa kepadatan stok cenderung lebih tinggi berada di bagian kawasan perairan Propinsi Jawa Tengah (selatan Cilacap), berturut-turut menuju ke arah timur (bagian Propinsi Jawa Timur) di peraiaran sebelah selatan Tulung Agung. Sebaliknya, pada bagian perairan selatan Jawa Tengah (wilayah Cilacap ke arah barat) dan bagian wilayah perairan selatan Jawa Timur (Tulung Agung ke arah timur) kepadatan stok relatif rendah (Gambar 4).

Sementara itu, di perairan barat Sumatera, kepadatan stok ikan Macrouridae relatif rendah, berkisar antara 0,85 sampai dengan $478,4 \mathrm{~kg} \mathrm{~km}^{-2}$ (Tabel 2). Rata-rata kepadatan stok sekitar 167,30 $\mathrm{kg} \mathrm{km}^{-2}$. Stok terpadat cenderung terkonsentrasi pada 2 wilayah, yaitu meliputi perairan di antara barat Banda Aceh sampai dengan Pulau Simeulu, dan sebagian di sekitar Pulau Enggano (Gambar 5). 
Tabel 3. Kepadatan stok ikan ekor tikus (Macrouridae) di perairan laut dalam selatan Jawa dan barat Sumatera

Table 3. Stock density of Macrouridae at south off Java and west off Sumatera deep sea

\begin{tabular}{|c|c|c|c|c|c|}
\hline \multicolumn{3}{|c|}{ Selatan Jawa/Southern Jawa } & \multicolumn{3}{|c|}{ Barat Sumatera/Western Sumatera } \\
\hline Stasiun/Station & Catch rate $(\mathrm{kg})$ & CPUA $\left(\mathrm{kg} \mathrm{km}^{-2}\right)$ & Stasiun/Station & Catch rate $(\mathrm{kg})$ & CPUA (kg km-2) \\
\hline 1 & 0,12 & 4,08 & 53 & 5,67 & 192,86 \\
\hline 2 & 4,24 & 144,22 & 54 & 8,6 & 292,52 \\
\hline 3 & 6,66 & 226,53 & 55 & 6,355 & 216,16 \\
\hline 4 & 22,55 & 767,01 & 56 & 1,99 & 67,69 \\
\hline 5 & 8,07 & 274,49 & 57 & 7,76 & 263,95 \\
\hline 6 & 2,245 & 76,36 & 58 & 9,445 & 321,26 \\
\hline 7 & 1,98 & 67,35 & 59 & 0,885 & 30,10 \\
\hline 8 & 8,51 & 289,46 & 60 & 14,065 & 478,40 \\
\hline 9 & 22,795 & 775,34 & 61 & 10,45 & 355,44 \\
\hline 10 & 19,335 & 657,65 & 62 & 1,08 & 36,73 \\
\hline 11 & 0,48 & 16,33 & 63 & 3,405 & 115,82 \\
\hline 12 & 8,045 & 273,64 & 64 & 6,865 & 233,50 \\
\hline 13 & 0,175 & 5,95 & 65 & 3,17 & 107,82 \\
\hline 14 & 3,545 & 120,58 & 66 & 7,56 & 257,14 \\
\hline 15 & 11,03 & 375,17 & 67 & 0,25 & 8,50 \\
\hline 16 & 13,155 & 447,45 & 68 & 1,655 & 56,29 \\
\hline 17 & 26,28 & 893,88 & 69 & 0,025 & 0,85 \\
\hline 18 & 0,125 & 4,25 & 70 & 7,67 & 260,88 \\
\hline 19 & 20,09 & 683,33 & 71 & 11,25 & 382,65 \\
\hline 20 & 10,125 & 344,39 & 72 & 1,335 & 45,41 \\
\hline 21 & 0,166 & 5,65 & 73 & 7,49 & 254,76 \\
\hline 22 & 1,7 & 57,82 & 74 & 8,105 & 275,68 \\
\hline 23 & 26,655 & 906,63 & 75 & 2,595 & 88,27 \\
\hline 24 & 4,48 & 152,38 & 76 & 2,91 & 98,98 \\
\hline 25 & 4,255 & 144,73 & 77 & 11,39 & 387,41 \\
\hline 26 & 9,17 & 311,90 & 78 & 3,225 & 109,69 \\
\hline 27 & 0,2 & 6,80 & 79 & 3,7 & 125,85 \\
\hline 28 & 4,635 & 157,65 & 80 & 4,22 & 143,54 \\
\hline 29 & 13,675 & 465,14 & 81 & 4,05 & 137,76 \\
\hline 30 & 9,86 & 335,37 & 82 & 0,495 & 16,84 \\
\hline 31 & 21,285 & 723,98 & 83 & 3,26 & 110,88 \\
\hline 32 & 35,9 & $1.221,09$ & 84 & 0,975 & 33,16 \\
\hline 33 & 0,82 & 27,89 & 85 & 2,805 & 95,41 \\
\hline 34 & 8,605 & 292,69 & 86 & 6,485 & 220,58 \\
\hline 35 & 17,035 & 579,42 & 87 & 6,405 & 217,86 \\
\hline 36 & 5,46 & 185,71 & 88 & 4,12 & 140,14 \\
\hline 37 & 9,89 & 336,39 & 89 & 7,915 & 269,22 \\
\hline 38 & 13,585 & 462,07 & 90 & 2,77 & 94,22 \\
\hline 39 & 31,625 & $1.075,68$ & 91 & 2,05 & 69,73 \\
\hline 40 & 11,685 & 397,45 & 92 & 6,42 & 218,37 \\
\hline 41 & 1,28 & 43,54 & 93 & 0,205 & 6,97 \\
\hline 42 & 1,445 & 49,15 & 94 & 3,7 & 125,85 \\
\hline 43 & 22,86 & 777,55 & 95 & 0,555 & 18,88 \\
\hline 44 & 3,61 & 122,79 & 96 & 0,325 & 11,05 \\
\hline 45 & 9,16 & 311,56 & 97 & 5,17 & 175,85 \\
\hline 46 & 0,57 & 19,39 & 98 & 2,18 & 74,15 \\
\hline 47 & 13,765 & 468,20 & 99 & 7,94 & 270,07 \\
\hline 48 & 1,73 & 58,84 & 100 & 11,2077 & 381,21 \\
\hline 49 & 8,165 & 277,72 & 101 & 8,93 & 303,74 \\
\hline 50 & 12,4 & 422,62 & & & \\
\hline 51 & 9,4 & 321,09 & & & \\
\hline 52 & 9,9300 & 337,76 & & & \\
\hline
\end{tabular}




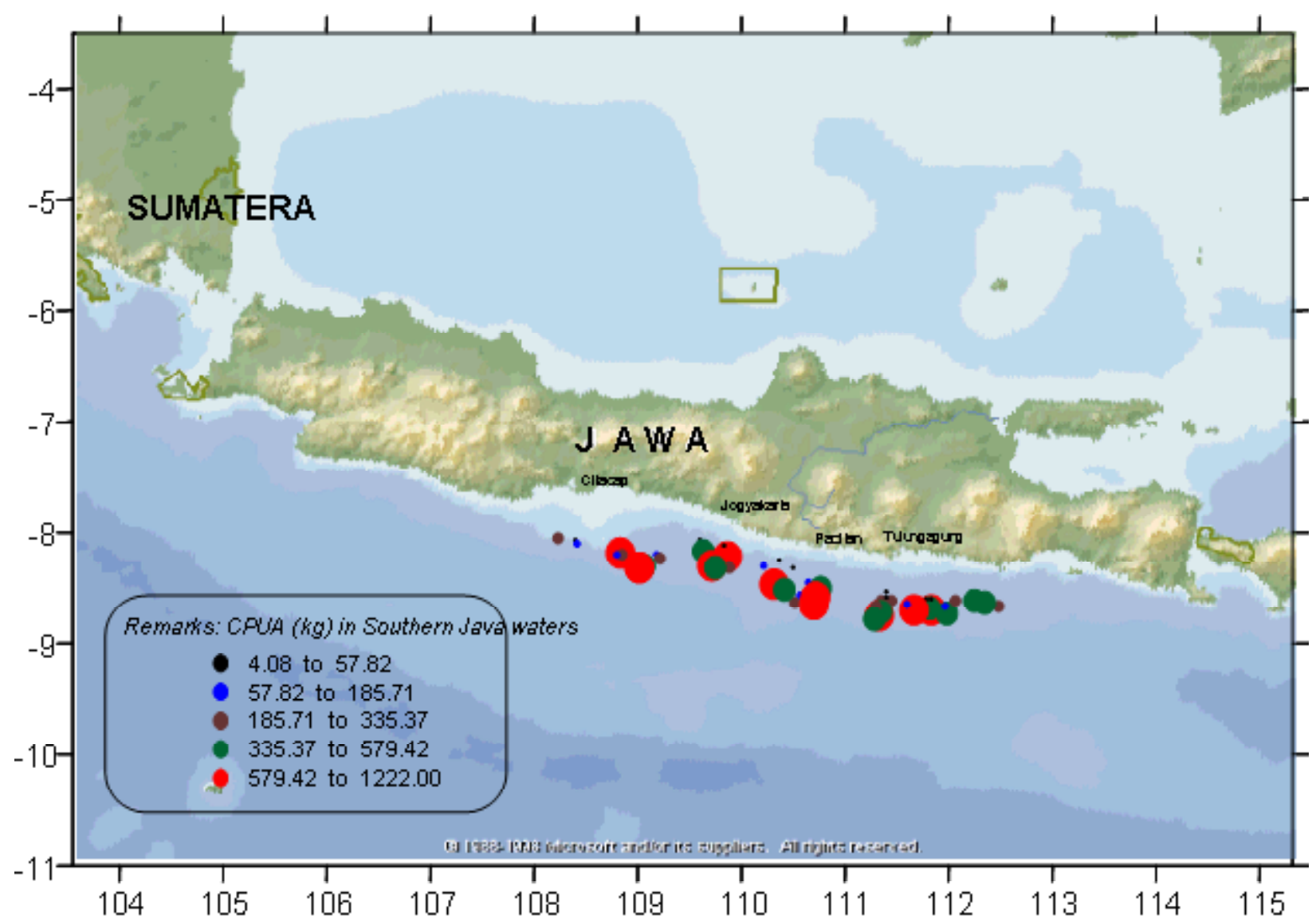

Gambar 4. Pola sebaran kepadatan stok ikan ekor tikus (Macrouridae) di perairan laut dalam sebelah selatan Jawa.

Figure 4. Patern stok density of Macrouridae in southern off Java deep sea.

Hasil penelitian Anggriani (1993), menginformasikan bahwa kepadatan stok ikan Macrouridae di perairan Kepulauan Kai dan Tanimbar 945,78 dan $2821,26 \mathrm{~kg} \mathrm{~km}^{-2}$, tampak lebih tinggi bila dibandingkan kepadatan stok di perairan selatan Jawa dan barat Sumatera.

Berdasarkan pada nilai rata-rata stok pada setiap strata kedalaman, diperoleh variasi kepadatan stok seperti tampak pada Gambar 6. Gambar tersebut memperlihatkan bahwa, kepadatan stok terendah ditemukan pada kedalaman relatif dangkal (200 sampai dengan $300 \mathrm{~m}$ ), kemudian cenderung meningkat seiring dengan bertambah kedalaman, di mana mencapai puncak tertinggi pada kedalaman 900 m. Pada kedalaman berikut (>900 sampai dengan $1.200 \mathrm{~m}$ ), kepadatan stok tampak menurun. Pola sebaran stok tersebut identik dengan hasil penelitian Wiguna, (1994) di perairan Tanimbar, di mana diinformasikan bahwa, sediaan stok ikan Macrouridae pada kedalaman 200 sampai dengan $300 \mathrm{~m}$, ditemukan paling rendah (141 kg km-2), kemudian cenderung meningkat menjadi $167 \mathrm{~kg} \mathrm{~km}^{-2}$ pada kedalaman 300 sampai dengan $400 \mathrm{~m}$ dan $148,9 \mathrm{~kg}$ $\mathrm{km}^{-2}$ pada kedalaman $1.000 \mathrm{~m}$. 


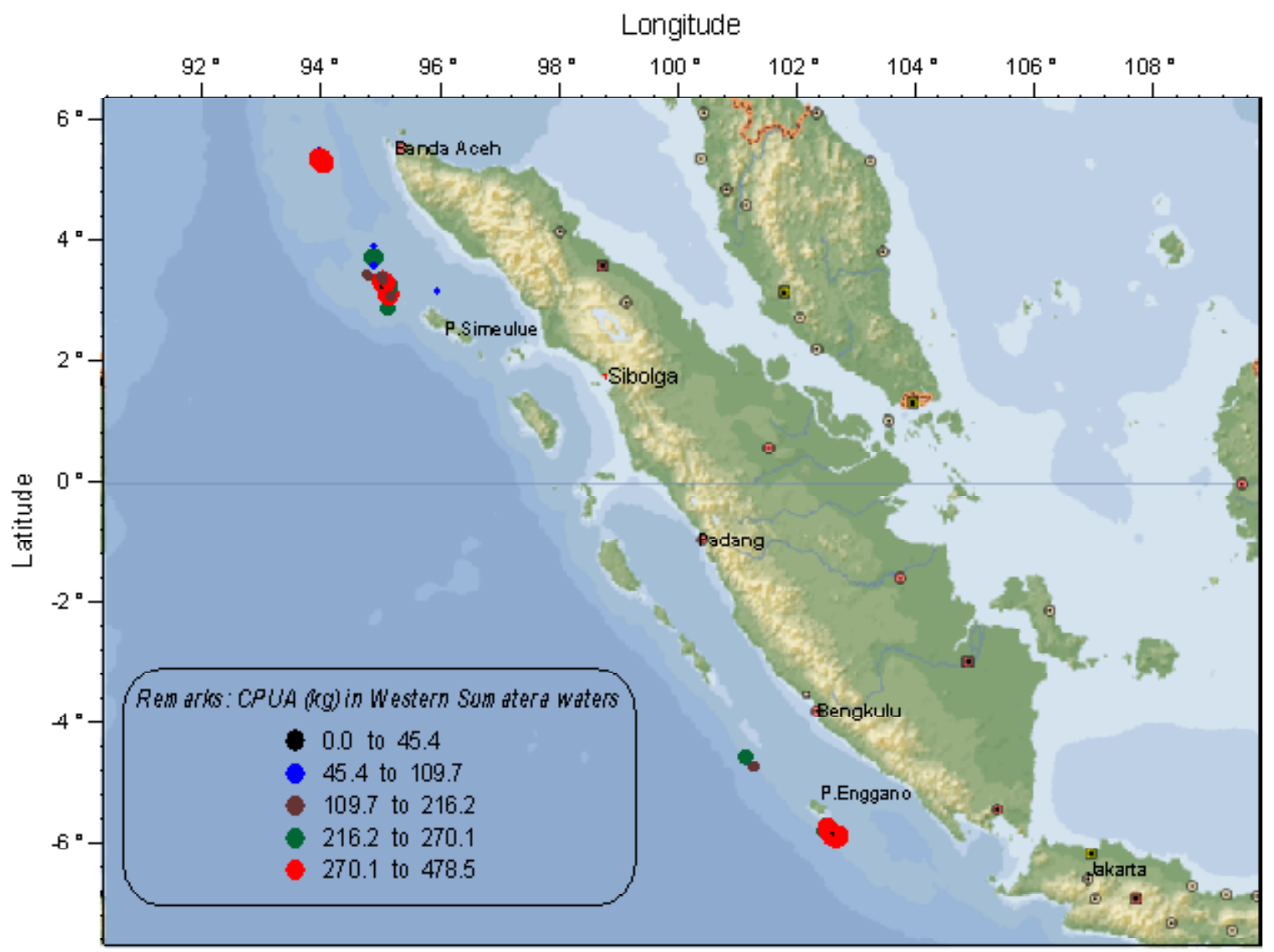

Gambar 5. Pola sebaran kepadatan stok ikan ekor tikus (Macrouridae) di perairan laut dalam sebelah barat Sumatera.

Figure 5. Patern stok density of Macrouridae in western off Sumatera deep sea.

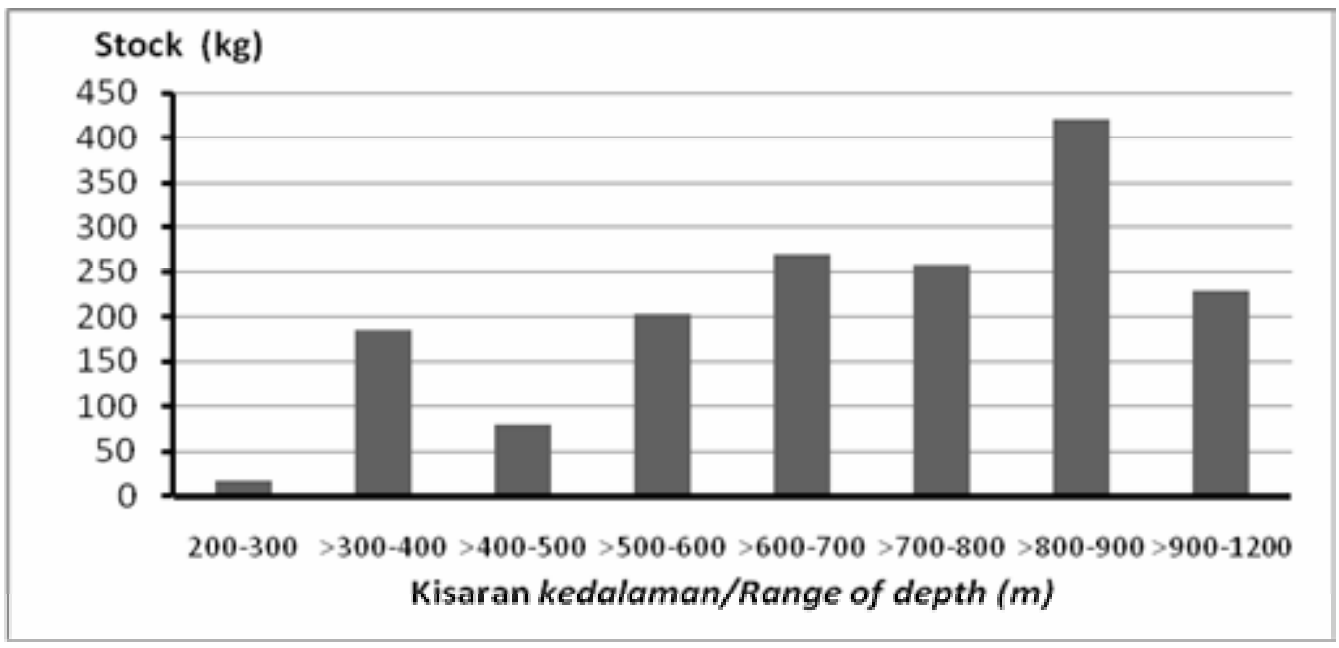

Gambar 6. Varisi kepadatan stok ikan ekor tikus (Macrouridae) pada setiap strata kedalaman di perairan laut dalam zona ekonomi eksklusif Indonesia Samudera Hindia.

Fidure 6. Variogram of Macrouridae stock density on the depth range in Indonesian ekslusive economic zone Indian Ocean deep sea. 


\section{KESIMPULAN}

1. Ikan ekor tikus (Macrouridae) yang tertangkap di perairan zona ekonomi eksklusif Indonesia Samudera Hindia terdiri atas 35 spesies, mewakili 11 genera. Hasil tangkapan didominansi oleh spesies Caelorinchus divergens dan Caelorinchus smithi. Spesies yang memperlihatkan penyebaran paling luas terdiri atas Coryphaenoides sp. 1 dan Macrouridae sp.1.

2. Penyebaran laju tangkap secara horisontal, paling tinggi ditemukan di perairan selatan Jawa, sebaliknya cenderung rendah di perairan barat Sumatera. Sedangkan secara vertikal, laju tangkap cenderung meningkat seiring dengan bertambah kedalaman perairan. Laju tangkap paling tinggi pada umumnya berada pada kedalaman mulai dari 500 sampai dengan $1.200 \mathrm{~m}$. Jumlah spesies ikan ekor tikus (Macrouridae) cenderung bertambah seiring dengan bertambah kedalaman perairan.

3. Kelimpahan stok ikan ekor tikus (Macrouridae) tertinggi ditemukan pada kedalaman 800 sampai dengan $900 \mathrm{~m}$ dan terendah pada kedalaman 200 sampai dengan $300 \mathrm{~m}$. Kepadatan stok di perairan sebelah selatan Jawa, berkisar antara 4 sampai dengan $1.221 \mathrm{~kg} \mathrm{~km}^{-2}$, rata-rata sekitar $336,53 \mathrm{~kg}$ $\mathrm{km}^{-2}$. Sedangkan di perairan barat Sumatera berkisar 0,85 sampai dengan $478,4 \mathrm{~kg} \mathrm{~km}^{-2}$, ratarata sekitar $167,30 \mathrm{~kg} \mathrm{~km}^{-2}$.

\section{PERSANTUNAN}

Kegiatan dari hasil riset the Japan-Indonesia deep sea fisheries resources, Joint Exploration Marine Resources, T. A. 2004 di Overseas Fishery Coorperation Foundation.

\section{DAFTAR PUSTAKA}

Anggrijani, T. 1993. Studi tentang kelimpahan stok bebebrapa jenis ikan demersal di perairan Kepulauan Kai dan Tanimbar. Skrips S-1. IImu dan Teknologi Kelautan. Fakultas Perikanan dan IImu Kelautan. Institut Pertanian Bogor. Bogor. 67 hal.

Badrudin, Wudianto, N. N. Wiadnyana, \& S. Nurhakim. 2006. Deep sea fish resources diversity and potential yield in the waters of western Sumatera of he east Indian Ocean. Indonesian Fisheries Research Journal. Vol.12. No.2. p.113127.
Badrudin, A. Suman, \& Awaludin. 2007a. Size distribution and maturity of the slimeheads (Hoplostethus crassispinus) in the deep sea around Simeuleu Island, Western Sumatera, Eastern Indian Ocean. Indonesian Fisheries Research Journal. Vol.13. No.1. p.9-16.

Badrudin, D. Nugroho, \& A. Suman. 2007b. The most abundance and the very rare species in the deep sea fish community in the western Sumatera, Eastern Indian Ocean. Indonesian Fisheries Research Journal. Vol.13. No.1. p.17-30.

Barton, R. 1977. The Ocean In Fleming, N. C. (eds). 1977. The Undersea. Macmillan Publishing Co. Inc. New York.

Carpenter, K. E. \& Niem V. H. (eds) 1999. FAO species identification guide for fishery purposes. The Living Marine Resources of the Western Central Pasific. Vol.3. Batoid fishes, chimaeras, and bony fishes part 1 (Elopidae to Linophrynidae). Rome. 406 pp.

Egletton, F. E. 1980. Abysal Animal In Humpreys. 1980. Encyclopedia International. Lexicon Publication Inc. U. S. A.

Frasser, H. T. 1975. Fishes of the world an illustrated dictionary. First Ameican Edition. Macmillan Publishing Co. Inc. New York.

Gloerfelt, T. T. \& P. J. Kailola. 1984. Trawled fishes of Southern Indonesia and Northern Australia. The Directorate General of Fisheries. Indonesia. 406 pp.

Guntara, A. 2004. Struktur komunitas ikan laut dalam secara vertikal di perairan sebelah selatan Cilacap, Samudera Hindia. Skripsi Fakultas Perikanan dan Ilmu Kelautan. Institut Pertanian Bogor. Bogor. 69 hal.

Midalsky, E. C. \& G. S. Fichter. 1983. The fresh and salt water fishes of the world. Greenwich House. Crown Publishers. Inc. New York.

Nakabo, T. 2002. Fishes of Japan, with pictoralkeys to the species. English Edition I and II. Tokay University Press. Tokyo. 1749 pp.

Nelson, J. S. 1984. Fishes of the world. $2^{\text {nd }}$. Willey Interscience Publication. John Willey and Sons. Toronto. 
Nybaken, J. W. 1988. Biologi laut: Suatu pendekatan ekologis. Alih Bahasa M. Eidman et al. Cetakan 1. Gramedia.480 hal.

Perkins, C. (Eds). 1992. Seafood handbook, the advance, selling the benefit. Taste Nutrition and Safety. Rocland. Maine U. S. A.

Suman, A., B. I. Prisantoso, F. Satria, dan E. Rahmat. 2007. Komposisi jenis, penyebaran, dan kepadatan stok ikan demersal laut dalam di perairan Samudera Hindia selatan Jawa dan barat Sumatera. Jurnal Penelitian Perikanan Indonesia. Vol.13. No.1. Hal.43-52.

Suseno, S. H., A. Suman, Wudianto, \& Arin, D. 2007. Nutrient and steroid contents of some deep sea fish species from western Sumatera, Eastern Indian Ocean. Indonesian Fisheries Research Journal. Vol.13. No.1 p.1-8.

Sparre, P. \& C. Venema. 1992. Introduction to tropical fish stock assesment. Part I. Manual. F. A. O. Fishery Tech. Pap. No.306/1.
Wudianto \& F. Satria. 2007. Identification of fishing ground for deep sea demersal fishes and it's possibility for fishing development in Indian Ocean. Indonesian Fisheries Research Journal. Vol.13. No.1. p.39-48.

Webber, H. H. \& H. V. Thurman. 1991. Marine Biology. $2^{\text {nd }}$ Eds. Harper Collins Publishers. U. S. A.

Widodo, J. 1980. Nilai hasil tangkapan ikan-ikan demersal hubungannya dengan faktor lingkungan abiotik di Laut Jawa. Buletin Penelitian Perikanan. Vol.1. No.1. Badan Penelitian dan Pengembangan Pertanian. Jakarta.

Wiguna, M. E.1994. Studi tentang ikan laut dalam di perairan Tanimbar, Kai, dan Aru. Kasus: Hubungan Keberadaan Ikan Pemangsa (Rexea prometheoides, Neopinnula orientalis, dan Cubiceps whiteleggi) dan Mangsa (Champsodon arafurensis dan Diaphus sp.). Skripsi S-1. Fakultas Perikanan dan Ilmu Kelautan. Institut Pertanian Bogor. Bogor. 131 hal. 